\title{
ÜRETIM SISTEMLERI VE TEKNOLOJILERINDEKI GELIŞMELERIN VE KÜ̈BESELLEŞMENIN GELENEKSEL MALIYET MUHASEBESINE ETKILERI
}

\author{
Dr. Aydmn Gersil \\ Adnan Menderes Üniversitesi \\ Iktisadi ve İdari Bilimler Fakültesi
}

\section{Özet}

Gerek üretim sistemleri ve teknolojilerindeki gelișmeler gerek küreselleşme muhasebe alanında çok derin etkilere neden olmaktadır. Üretim sistemlerinin yapısı ve işleyişindeki değişimler, muhasebe ve maliyet muhasebesi sistemlerinde de farklı yaklaşımların geliştirilmesini zorunlu kılmaktadır. Küreselleșme de, işletme yönetiminin muhasebe sisteminden ve maliyet muhasebesinden beklentilerinin artmasına neden olmaktadır. Maliyet muhasebesi alanında geliştirilen yaklaşımların en önemli özelliği, işletmenin bölümleri arasındaki koordinasyonun geliştirilmesi gerektiğini ortaya koymasıdır. Modern maliyet muhasebesinin çıktıları işletmenin bütününü kapsamaktadır. Bu nedenle modern maliyet muhasebesinin çıktıları işletmenin diğer bölümlerinin çıktıları ile birlikte değerlendirilmelidir. Geleneksel muhasebe ve maliyet muhasebe sisteminin çıktıları işletmeyi bir bütün olarak değerlendirmede yetersiz kalmaktadır. Bugünün işletmecilik dünyasında geleneksel muhasebe sistemi ve geleneksel maliyet muhasebesinin çıktılarına dayalı olarak alınacak kararlar hatalı sonuçların ortaya çıkmasına neden olacaktır. Bu durum işletmelerin rekabet gücünü zayıflatacaktır.

Anahtar Kelimeler: Modern maliyet muhasebesi, küreselleşeme, modern üretim sitemleri ve teknolojileri, maliyet yönetimi, stratejik maliyet yönetimi.

Effects on Traditional Accounting of Developments in the Production Systems and Technologies and Globalisation

\begin{abstract}
Both developments in the manufacturing systems and techonologies and globalisation have casued great deep effects on accounting area. In production systems's construction and working changes have forced to development different methods in accounting and cost accounting's systems. Globalisation have caused to raise business management's expectations from accounting system and cost accounting, too. The most important feature of new methods which were developed in the cost accounting area is that shows necessity to improve among deparmants of business coordination. Modern cost accounting's outputs cover entire business. Therefore, modern cost accounting systems's outputs must be evaluated with other departmants's outputs. Traditional accounting and cost accounting systems's outputs aren't enough to evaluate entire business. Today, in the business world, which is taken decisions based on traditional accounting and cost accounting systems's outputs will cause wrong results. This is weaken business's competition force.
\end{abstract}

Keywords: Modern cost accounting, globalisation, modern production systems and techonologies, cost management, strategic cost management. 


\section{Üretim Sistemleri ve Teknolojilerindeki Gelişmelerin ve Küreselleşmenin Geleneksel Maliyet Muhasebesine Etkileri}

\section{GíRiş}

1980'li yıllardan itibaren, küreselleşmenin etkisiyle, işletmeler arasındaki rekabetin boyutları değişmeye başlamıştır. İşletmeler yeni rekabet koşullarına uyum sağlamak için yeni çözüm arayışlarına yönelmişlerdir. Bu dönemlerden itibaren özellikle üretim, yönetim, pazarlama ve bilgi teknolojileri alanlarında çok hızlı gelişmeler olmaktadır. İşletmelerin bu değişen rekabet koşullarına uyum sağlamasında en önemli unsurlardan birisi, üretim sistemi ve teknolojisidir. Üretim sisteminin tüketici isteklerine hızlı bir şekilde ve istenen kalitede cevap verebilmesi, üretim sisteminin yüksek seviyede otomasyonunu ve aynı zamanda üretim sisteminin esnekliğinin yüksek olmasını gerektirmektedir. Genel bir ifadeyle, rekabet için üretim sisteminin kalite, hız, esneklik ve sürekli gelişim özelliklerine sahip olması gerekmektedir. Kuşkusuz üretim sistemleri ve teknolojilerindeki gelişmelere paralel olarak muhasebe sistemi ve maliyet muhasebesi sisteminde de değişim kaçınılmaz olmaktadır. Üretim sistemine ve teknolojisine uygun olmayan muhasebe ve maliyet muhasebe sistemi de hatalı sonuçlar üretecektir. Bu çalışmada üretim sistemleri ve teknolojilerindeki gelişmelerin ve küreselleşmenin geleneksel maliyet muhasebesine etkileri incelenmiştir.

\section{1. ÜRETIM SISTEMLERi VE TEKNOLOJILERIN- DEKI GELIŞMELER}

$\mathrm{Bu}$ alandaki gelişmeler, bilgisayarlı entegre üretim, esnek üretim, tam zamanında üretim ve toplam kalite yönetimi olarak ifade edilebilir. 


\subsection{Bilgisayarlı Entegre Üretim}

Bilgisayarlı entegre üretim (BEÜ) (Computer İntegrated Manufacturing) sisteminde tüm tasarım-üretim faaliyetleri, merkezi bir bilgisayar birimi tarafından yürütülmektedir. Bu üretim sisteminde kalite düzeyi çok yüksek ürünler üretilebilmektedir. Ayrıca, ürünlerin işletmede bekleme süresi asgari düzeye inmektedir. Bu sistem, bilgisayar destekli tasarım, bilgisayar destekli üretim ve bilgisayar destekli mühendislik gibi alt sistemlerin bir arada kullanılmasını gerektirmektedir. Bütün bu faaliyetlerin bilgisayarlar aracıllğı ile birbirine bağlı şekilde yürütülmesi, bu faaliyetlerin kısa bir zaman periyodunda gerçekleşmesini sağlamaktadır. Bilgisayar destekli tasarımda bir ürünün bileşenlerine ait bilgiler, bilgisayar sistemine yüklenerek bileşenlerin tasarımı gerçekleştirilmektedir. Böylece, ürün bileşenlerine ait çizimlerin hem hızlı bir şekilde hem de istenilen nitelikte oluşturulması sağlanmaktadır (Kobu, 2003: 139-140).

Bilgisayarlı entegre üretimin diğer bir önemli parçası olan bilgisayar destekli üretimde, üretim sürecinin planlanmas1, yönetimi ve kontrolü bilgisayar sistemi ile gerçekleştirilmektedir. $\mathrm{Bu}$ sistemlerin birlikte kullanılması, tasarım verimliliğini arttırmakta, tasarım - deneme üretiminin süresini kısaltmakta, ürün bileşenlerinin sayısı azalmakta ve önemli ölçüde maliyet tasarrufu sağlamaktadır (Güneş vd., 1999: 87-88).

\subsection{Esnek Üretim Sistemi}

Esnek üretim sistemi (EÜS), sayısal kontrollü birbirine benzer makine grubundan oluşan bir sistemdir. Bu sistemde aynı işlem farklı makinelerde yapılabilmektedir. Sistemin bu özelliği, makinelerden birinin arızalanması durumunda üretim akışının aksamasını önlemektedir (Kobu, 2003: 140). EÜS'de, faaliyetlerin çok büyük bir kısmı robotlar tarafindan yerine getirilmektedir. Bu nedenle işgücünün üretim sürecine direkt katkısı çok düşük düzeylerde gerçekleşmektedir. Direkt işçiliğin üretim faaliyetlerine katkı düzeyinin düşmesiyle birlikte, endirekt işçiliğin (tasarım, bakım onarım, mühendislik faaliyetleri) katkı payında yükselme olmuştur.

EÜS, İşletmelerin ürünlerine yönelik talebe zamanında cevap verebilmek için üretim koşullarının esnek olmasını sağlamaktadır. Bu sistem ile geleneksel üretim sistemlerine göre hem çok sayıda farklı ürün üretilebilmekte hem de üretimin çeşitlenmesi ile yarı ürün ve ürün stok düzeyi çok düşük düzeylere çekilebilmektedir. 


\subsection{Tam Zamanında Üretim}

Tam zamanında üretim yöntemi (TZÜY), "bir organizasyon içindeki gerekli faaliyetlerin, sadece ilgili bölümlerce gereksinme duyulduğu zamanlarda ve sadece gereken kapsam ve düzeylerde gerçekleştirilmesi”ni hedefleyen bir yöntemdir (Hacırüstemoğlu/Şakrak, 2002: 65). Tam zamanında üretim yöntemi 1970'li yıllarda Toyota işletmesinde geliştirilmiştir. Geleneksel üretim sistemlerinde önemli bir yer tutan stoklar, tam zamanında üretim yöntemi ile çok düşük düzeylere hatta sıfır düzeyine bile çekilebilmektedir. Bu yöntemde, stokların üretim sürecindeki kusurların gizli kalmasına neden olduğu kabul edilmektedir. Stok miktarı azaldıkça, üretim faaliyetlerindeki kusurlar ortaya çıkacaktır. TZÜY'nün etkin bir şekilde çalışabilmesi için beş koşul gereklidir (Kobu, 2003: 371):

- Talep kadar üretim yapılmalıdır.

- Üretimin hızı ile talebin değişim hızı uyumlu olmalıdır.

- Makinelerin hazırlık süreleri kısa olmalıdır.

- Üretim sürecindeki israflar önlenmelidir.

- İşgücü sürekli eğitime tabi tutulmalı ve gelişimi teşvik edilmelidir.

TZÜY, geleneksel üretim sistemlerinin aksine çekme prensibine göre işlemektedir. Hiçbir istasyonda herhangi bir üretim emri gelmeden üretim yapılmamaktadır. Üretim sürecindeki her istasyon, bir sonraki istasyondan gelecek üretim emrini beklemektedir. TZÜY'de sıfir hata ve israfların olmaması için, her istasyon diğerinden gerekli kalite düzeyinde ilk madde ve malzeme talep etmektedir. TZÜY toplam kalite yöntemi ile birlikte uygulanmaktadır. TZÜY'nün başarısı için işgörenlerin tümünün bu yaklaşımı benimsemesi gereklidir ve işgörenlerin sürekli gelişimi teşvik edilmelidir (Demir/Gümüşoğlu, 2003: 718). TZÜY'de işgörenler çok yönlü olmak durumundadır. İşgörenler sadece üretim faaliyeti ile değil, aynı zamanda makinelerin ve diğer ekipmanların bakımından da sorumlu olmaktadırlar. Ayrıca, herhangi bir işgören üretim hattında bir aksaklık saptadığında üretim hattını durdurmaya yetkilidir. $\mathrm{Bu}$ fonksiyonlara ilaveten işgören, üretim sürecinde kullanılan malzemelerden nihai ürüne kadarki tüm aşamalara kadar kalite denetimi yapmakla yükümlüdür (Çelikçapa, 1999: 169).

TZÜY'de diğer bir önemli unsur faaliyetler üzerine yoğunlaşmadır. Faaliyetler, bir firma tarafından amacına ulaşmak için yapılan işlerdir. TZÜY'nün temel amac1 değer yaratmayan faaliyetleri tamamen ortadan kaldırmak veya en düşük düzeye indirmektir. Değer yaratan faaliyetleri ise olabildiğince arttırmaktır. Adından da anlaşılacağı gibi değer yaratan bir faaliyet, bir ürünün müşteri ihtiyaçlarını tatmin etme özelliğine katkıda bulunan 
herhangi bir çalışmadır. Değer yaratmayan faaliyetler ürünün müşterinin ihtiyaçlarını tatmin etme özelliğine katkıda bulunmayan görevleri üstlenir. Örneğin bir firının 1sınmasını beklemek tüketici açısından bir değer yaratmaz. Çünkü tüketicilerin çoğu yemeğin pişmesine değer verir fakat bunun için beklemeye değer vermez (Edmands vd., 2003: 22). TZÜY'de, bir ürünün üretim sürecindeki faaliyetlerin değer yaratan - değer yaratmayan faaliyetler olarak ayrımı üretim sürecinin bütünü göz önünde bulundurularak yapılmaktadır. Bir ürünün üretim süreci, üretim, kontrol, taşıma, bekleme ve depolama zamanlarının toplamından oluşmaktadır. Üretim süreci bütün olarak değerlendirildiğinde, bu zamanlar içerisinde yalnızca üretim zamanının ürüne değer katan zaman olduğu görülmektedir. Bu nedenle, TZÜY değer katmayan zamanlar üzerine yoğunlaşarak bu zamanları azaltmaya, üretim zamanının toplam süre içerisindeki payını arttırmaya çalışmaktadır. Nihai hedef, üretim zamanının payını, toplam süre içerisinde yüzde yüze çıkartmaktır (Yükçü, 2000: 21). TZÜY'nün etkin bir şekilde çalışmasında, bilgisayar destekli tasarım ve bilgisayar destekli üretim de önemli bir rol oynamaktadır. Bu teknikler ile tam zamanında üretim yöntemi amaçlarına ulaşmaktadır.

\subsection{Toplam Kalite Yönetimi}

Toplam kalite yönetimi (TKY), tüketici tatminini esas alarak, kaliteyi işletmenin bütününe yayma amacı taşıyan bir sistemdir. Geleneksel üretim yöntemlerinde kalite süreci, ürünün üretiminin tamamlanmasından sonra başlamaktadır. TKY'de ise kalite sürecinin başlangıcı, ürünün tasarım aşamasıdır. $\mathrm{Bu}$ yaklaşım sayesinde kaliteyle ilgili problemlere kaynağında müdahale etme olanağı doğmaktadır. TKY anlayışı kalitenin sorumluluğunu işletmenin bütününe yaymaktadır. Dolayısıyla, hedeflenen kalite düzeyine ulaşmada herkesin katkısı önemli olmaktadır. TKY işletme yönetiminde katılımcılığın önünü açmaktadır (Top, 2001:209-210). TKY ve TZÜY birbirini tamamlayan yaklaşımlardır. Her ikisi de genel olarak aynı prensiplere sahiptir. Tam zamanında üretim yönteminin sıfır hata, değer yaratmayan faaliyetlerin ortadan kaldırılması, üretim sürecinde ortaya çıkan problemlere kaynağında ve bir daha ortaya çıkmayacak şekilde müdahale edilmesi, israfların önlenmesi gibi hedefleri, bu yöntemin TKY ile eş zamanlı olarak uygulanmasını gerektirmektedir. TKY'nin uygulamadaki başarısını bir çok faktör etkilemektedir. ŞEKILL.1'de TKY'nin başarılı bir şekilde uygulanmasını etkileyen önemli faktörler yer almaktadır. 
- Ankara Üniversitesi SBF Dergisi • 62-4

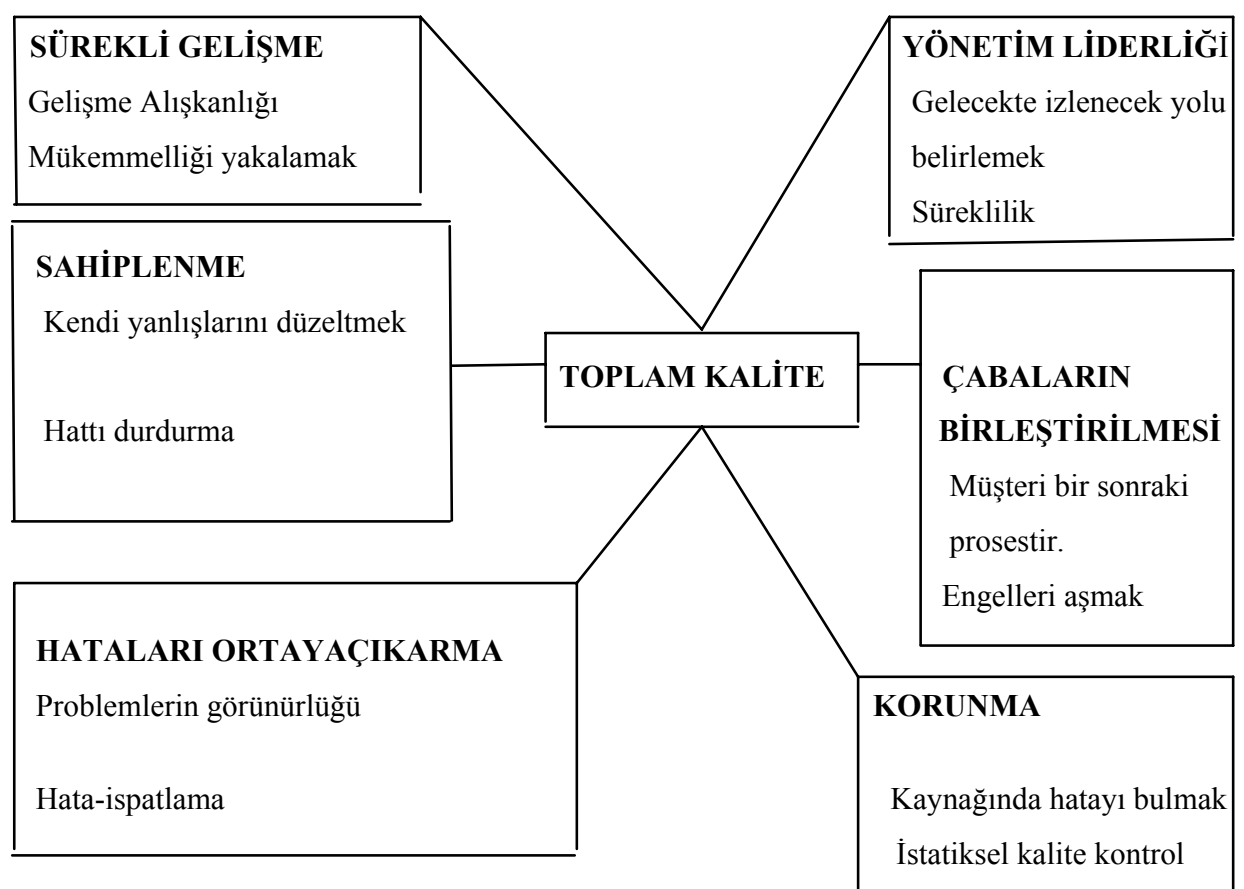

Şekil.1: Toplam kalite yönetiminde anahtar faktörler

Kaynak: (Çetinkaya, 2000: 299)

Yönetim liderliği, işletme yönetiminin denetleyici olmasından ziyade, liderlik vasfının daha ön plana çıkartılmasıdır. Yönetim, işletmeyi yarınlara taşıyacak doğru projeksiyonlar üretebilmelidir. İşletmedeki çabaların birleştirilmesi, işletmedeki tüm süreçlerin bir araya getirilerek birleștirilmesini ifade etmektedir. Birleştirilen süreçte, sıralı işlemler dizisinde işlemleri yapanlar kendilerinden önceki işlemleri yapanların müşterileri olmaktadır. Korunma; süreçte oluşan hatalara kaynağında, hataların bir daha ortaya çıkmaması şeklinde müdahale edilmesi gerektiğini belirtmektedir. Hatalara kaynă̆ında müdahale etmenin sağlayacağı maliyet tasarrufu, hatalara sürecin sonunda müdahale etmenin sağlayacağı maliyet tasarrufundan daha fazla olacaktır. Hata ortaya çıktığı zaman, tüm çabalar hatayı ortadan kaldırmaya yönelik olmalıdır. Hatanın gizlenmesi ise, toplam kalite yönetiminin uygulamasına önemli ölçüde zarar verecektir. Hataya kaynağında müdahale etmenin sağlayacağ 1 avantajlar kaybedilecektir. Sahiplenme, işgörenlerin sürecin hatasız bir şekilde işlemesinden sorumlu olduğunu ifade etmektedir. İşgörenler, hem o işi yapmaktan, hem de o işin kalitesinden sorumludur. Sürekli 
gelişme, tam zamanında üretimin nihai amacı olan sıfır hata hedefine ulaşma çabasıdır. Sıfır hata hedefine ulaşılması, tüm süreçlerin kontrol altında olmasını ifade etmektedir. Sıfır hata hedefi, çalışanların yönetime katılımı, takım çalışması, kalite çemberleri gibi tekniklerin uygulanması ile sağlanmaktadır (Çetinkaya, 2000: 298-300).

\section{GELENEKSEL ÜRETIM SISTEMLERI ILE MO- DERN ÜRETIM SISTEMLERININ KARŞILAŞTIRILMASI}

Geleneksel üretim sistemleri (GÜS) ile modern üretim sistemleri (MÜS) karşılaştırıldığında pek çok yönden farklılıklar görülmektedir.

GÜS'de, itme prensibine göre üretim yapılmaktadır. MÜS'de ise çekme prensibine göre üretim yapılmaktadır. Çekme prensibinde hiç bir istasyon kendisinden sonraki istasyondan üretim emri gelmedikçe faaliyete geçmemektedir. Böylece, istasyonlar arasında stok birikmesinin önüne geçilmiş olunmaktadır. Çekme prensibi, üretim sürecindeki tüm faaliyetlerin eş zamanlı koordinasyonunu gerektirmektedir. İtme prensibinde ise istasyonlar arasında stok birikimi olmaktadır. Ayrıca, itme prensibinde üretim sürecindeki faaliyetler arasında eş zamanlılık yoktur. Faaliyetler birbirini takip etmektedir.

MÜS'de, yüksek teknolojinin kullanılması ve otomasyonun artması, işgücünün üretim faaliyetlerine direkt katkısını azaltmıştır. GÜS'de otomasyonun ve teknolojinin düşük seviyede olmasından dolayı, üretim faaliyetlerine direkt katılan işgücü sistemin önemli bir unsuru olmuştur. MÜS'de ise otomasyonun artması ve yüksek teknolojinin kullanımı, üretim sürecinde uzmanlaşmış işgücünün (tasarım, mühendislik, bakım onarım) yoğun bir şekilde kullanımını gerektirmektedir.

MÜS'de yüksek teknolojinin kullanılması ve otomasyonun artması, yüksek maliyetli teknolojik yatırımların yapılmasını gerektirmektedir. Dolayısıyla, bu teknolojik yatırımların maliyetleri ve bu maliyetlerin yönetimi de önem kazanmaktadır. GÜS düşük teknolojili sistemler olduğu için, teknolojik yatırımların maliyetleri ve bu maliyetlerin yönetiminin önem derecesi MÜS'dekine göre daha düşük olmaktadır.

GÜS'de kitle veya sipariş tarzı üretim yapılmaktadır. Kitle halinde üretimde, birbirine benzer ürünler yığın halinde üretilmektedir. Sipariş tarzı üretimde ise üretilen ürünlerin çeşitliliği sınırlı sayıdadır. Bu üretim tarzında üretilen partilerin büyüklüğü de belli bir büyüklükte olmaktadır. MÜS'ün esnek yapısı, hem ürün çeşidi sayısının çok daha fazla olmasını, hem de üretilen partilerin daha küçük boyutta olmasını sağlamaktadır. MÜS'de TKY'nin uygulanması ile kalite faaliyetleri üretim sürecinin her aşamasına 
yayılmaktadır. GÜS'de ise kalite faaliyetleri daha çok üretim sürecinin sonrasında yoğunlaşmaktadır. Kalite faaliyetlerinin üretim sürecine yayılması, geleneksel üretim sistemlerinde dikkate alınmayan kalite maliyetlerinin ve kalite yönetiminin de önem kazanmasını sağlamaktadır.

GÜS'de sadece üretim sürecine yoğunlaşılırken, MÜS'de üretim süreci dışında, üretim öncesi ve üretim sonrası süreçler de dikkate alınarak üretim yapılmaktadır.

\section{3. ÜRETIM SISTEMLERI VE TEKNOLOJILERIN- DEKi GELIŞMELERIN GELENEKSEL MALIYYT MUHA- SEBESINE ETKILERI}

Üretim sistemleri ve teknolojilerindeki gelişmelerin ve küreselleşmenin geleneksel maliyet muhasebesine etkileri çok yönlü olmaktadır. Genel olarak bu etkiler beş başlık altında ifade edilebilir:

\subsection{Geleneksel Maliyet Muhasebesinin Yetersizlikleri}

MÜS'ü uygulayan işletmelerde, geleneksel maliyet muhasebesi ve yönetim muhasebesi sistemlerinin yetersizlikleri beş grupta toplanabilir (Lucey, 2000: 477-478):

- Dağıtım anahtarı: Geleneksel maliyet muhasebesi ürün maliyetini, üretim-hacmi ile ilgili dağıtım anahtarları temelinde tam maliyetleme yöntemini kullanarak hesaplamaktadır. Modern üretim sistemlerinde, ürün maliyetinin hesaplanmasında hacim tabanlı yükleme oranlarının kullanılması, bu sistemlerin yapısına uygun düşmemektedir. Çünkü modern üretim sistemlerinde üretim hacmi ile ilgili olmayan faaliyetlerin oluşturduğu maliyetlerin ürün maliyeti içerisinde ağırlıklı bir paya sahip olması, hacim tabanlı dağıtım anahtarlarının geçerliliğini yitirmesine neden olmaktadır.

- Maliyet davranış1: Geleneksel maliyet ve yönetim muhasebesi maliyetleri üretim hacmiyle bağlantılı olarak sabit ve değişken maliyetler şeklinde sınıflandırmaktadır. Modern üretim sistemlerinde ise, özellikle genel üretim giderlerinin büyük bir kısmı üretim hacmi dışındaki faaliyetlerle ilgilidir. $\mathrm{Bu}$ nedenle, sabit ve değişken maliyet ayırımının yeniden gözden geçirilmesi gereklidir.

- Standart maliyetleme yöntemi: Standart maliyetleme yöntemi, modern üretim sistemleri ve tam zamanında üretim ortamları için yararlılığı sorgulanan geleneksel kontrol tekniklerini kullanmaktadır. Standart maliyet yönteminde önceden belirlenmiş standartlara erişilmesi durumunda işletme performansının 
yeterli sayılması düşüncesi, modern üretim sistemlerindeki sürekli gelişim felsefesi ile karşıt düşmektedir. Diğer yandan, dönem sonlarında üretilen finansal rakamlara odaklanan fark analizleri, işletme yönetiminin bilgi ihtiyacını zamanında karşılamada çok az bir değere sahip olmaktadır. Fark analizinde yer alan birçok fark kavramı, modern üretim sistemleri ortamlarında önemini kaybetmektedir. Örneğin; fiyatların; kalite ve tedarikçi güvenilirliğinin önemli faktörler olduğu uzun dönemli anlaşmalarla belirlenmesi durumunda, alım fiyat farkları çok anlamlı olmayacaktır. Daha ucuz malzeme satın alma fiyatına ulaşmak için büyük hacimli alım felsefesi sıfır stokla çalışmaya yönelik modern üretim sistemlerinin felsefesi ile çatışmaktadır.

- Kısa dönem finansal ölçütler: Geleneksel yönetim muhasebesi çıktılarının büyük bir kısmı; maliyetler, birim maliyetle ölçülen üretim verimliliği, farklar vb. kısa dönem finansal performans ölçütlerinden oluşmaktadır. $\mathrm{Bu}$ bilgilerin büyük bir kısmı dönem sonunda üretilmekte ve dar odaklı olmaktadır. Modern üretim sistemleri hem daha hızlı ulaşılabilen finansal ve finansal olmayan performans ölçütlerine hem de daha geniş bir bakış açısına ihtiyaç duymaktadır.

- Maliyet muhasebesi kayıt süreci: Geleneksel maliyet muhasebesi, ilk madde ve malzemeleri, yarı mamul-üretim hesabı üzerinden, çeşitli üretim aşamalarında ve üretimi tamamlanmış ürünler boyunca takip etmektedir. Bu süreç, binlerce işlem girişiyle desteklenmektedir. Tam zamanında üretim yönteminde sürekli olarak sıfıra yakın stokla çalışıldığ 1 için, geleneksel maliyet muhasebesindeki bu kayıt süreci daha basit bir süreç haline gelmektedir.

\section{2. Üretim Maliyetleri Bileşiminde ve Dağıtım Anahtarlarında Meydana Gelen Değişim}

Modern üretim sistemlerinde teknolojik yatırımların artan oranda yer alması, özellikle iki maliyet kalemi üzerinde önemli etkilere yol açmıştır: Direkt işçilik giderleri ve genel üretim giderleri. Otomasyonlaşmanın artması, üretim maliyetleri içerisinde genel üretim giderlerini en önemli maliyet kalemi haline getirirken, direkt işçilik giderlerinin üretim maliyetleri içerisindeki payını da çok düşük düzeylere indirmiştir. GÜS'de, üretim işgücünün yoğun katkısı ile gerçekleşirken, MÜS'de üretim otomasyon ve robotlar ile yapılmaktadır. Dolayısıyla, bu üretim sistemlerinde işgücünün üretime katkısı sınırlı olmaktadır. Bu gelişme de, üretime direkt katılan işgücünün oluşturduğu direkt işçilik giderlerinin üretim maliyetleri içerisindeki payının önemli ölçüde azalmasına yol açmışır. 
Diğer yandan, genel üretim giderleri kapsamında yer alan üretim mühendisliği, planlama ve makine kurulum faaliyetleri, otomasyon, satış sonrası hizmetler, bakım onarım vb. gibi faaliyetlerin önem kazanması nedeniyle destek maliyetleri önemli bir maliyet kalemi haline gelmiştir. Genel üretim giderlerinin daha önemli hale gelmesine ilaveten, dağıtım, satış, pazarlama ve yönetim faaliyetleriyle ilgili dolaylı maliyetler de, direkt işgücü maliyetlerinin düşmeye devam etmesiyle birlikte önemli oranda yükselmiştir. Maliyet yapısındaki bu değişimler, yüksek oranda direkt işgücüyle üretim için tasarlanmış olan geleneksel maliyet sistemlerinin yetersiz kalmasına neden olmuştur. Geleneksel üretim sistemlerinde destek faaliyetleri düşük yoğunlukta olması nedeniyle bunların nasıl ortaya çıktığını veya maliyetlere nasıl tahsis edileceğini anlamak önem teşkil etmemektedir. Çünkü bu maliyetlerin tahsisi ürün maliyeti değişimlerini yönlendirecek düzeyde değildir. Destek faaliyetlerinin maliyetlerinin toplam üretim maliyetlerinde belirgin bir paya erişmesi nedeniyle yöneticiler bunları anlamalı ve analiz etmelidirler. $\mathrm{Bu}$ nedenle, bugünkü maliyet muhasebesi sistemlerinin tasarımcıları, destek faaliyetlerinin maliyetlerine özel önem vermelidirler (Atkinson vd., 1997: 94-95).

Destek maliyetlerini de kapsayan genel üretim giderleri, geleneksel üretim ortamında üretim maliyetleri içerisinde nispeten düşük pay alırken, yeni üretim ortamlarında üretim maliyetleri içindeki payını önemli ölçüde arttırmıştır. Genel üretim giderlerindeki artışın en önemli nedeni, modern üretim sistemlerinin yüksek maliyetli sabit yatırımlara sahip olmasıdır. MÜS'ün teknolojik yatırımlara sahip olması nitelikli işgücünü gerektirmektedir. Nitelikli işgücündeki artış endirekt işçilik giderlerinin önemli oranda artmasına neden olmaktadır. Ayrıca, günümüzün rekabetçi pazarlarında ürünlerin tasarım özelliklerinin ön plana çıkması, modern üretim sistemlerinde üretim öncesi (ürün tasarım, ürün planlama) safhalara yoğunlaşılması gereğini zorunlu kılmıştır. Dolayısıyla, mühendislerin üretim sürecine katkısı daha da fazlalaşmıştır. Tasarım ve planlama aşamasında yüksek teknolojiye sahip sistemlerin kullanılması, bu aşamaların maliyetlerinin yükselmesine neden olmuştur. Bir ürünün toplam yaşam seyri maliyetinin büyük bir kısmının üretim öncesi safhalarda alınan kararlara bağlı olarak yönetilebilmesi, maliyet hesaplamalarında üretim öncesi safhaların da dikkate alınmasını gerektiren önemli bir unsur olmaktadır. Çünkü günümüzün rekabet ortamında geleneksel fiyatlama yaklaşımı "maliyet + kar marjı = fiyat" yerini "hedef satış fiyatı hedef kar marjı = hedef maliyet yaklaşımına bırakmıştır. Dolayısıyla geleneksel yaklaşımda olduğu gibi ürünü tasarlama, üretme ve satış fiyatını belirleme yerine, ürünü üretmeden önce o ürünün hedef maliyetini belirleyerek, hedef maliyete uygun ürün tasarımını ve ürünün üretimini gerçekleştirmek gereklidir. Böylece o ürün için öngörülen yaşam süresi boyunca ortaya çıkan tüm 
maliyetleri yönetme şansına da sahip olunacaktır. Ürünün tüm yaşam süresince ortaya çıkması muhtemel maliyetlerin önceden yönetilebilmesi ürünün kavram ve tasarım aşamasında verilen kararlara bağlıdır. Ürün tasarlanıp üretime geçildikten sonra maliyet tasarrufu çalışmaları istenenen sonucu vermeyecektir (Cokins, 1996 :30). Ayrıca, MÜS daha fazla sayıda maliyet kaleminin direkt izlenebilirliğini de arttırmıştır. Diğer bir ifadeyle, geleneksel maliyet sisteminde endirekt gider olarak kabul edilen birçok maliyet kalemi, yeni üretim ortamlarında direkt gider olarak kabul edilmektedir. $\mathrm{Bu}$ nedenle, maliyetlerin direkt-endirekt olarak ayrımı modern üretim sistemlerine uygun olarak yapılmak durumundadır. $\mathrm{Bu}$ ayrıma bir örnek TABLO.1'de yer almaktadır. Modern üretim sistemi olarak, tam zamanında üretim yöntemi esas alınmıştır.

Tablo.1: Geleneksel ve tam zamaninda üretim yöntemlerinde direkt ve endirekt maliyetler

\begin{tabular}{|l|c|c|}
\hline Maliyetler & Geleneksel Üretim & Tam Zamanında Üretim \\
\hline Direkt İlk Madde ve Malzeme & Direkt & Direkt \\
\hline Direkt İşçilik & Direkt & Direkt \\
\hline İşletme Malzemesi & Endirekt & Direkt \\
\hline Enerji & Endirekt & Direkt \\
\hline Malzeme Nakli & Endirekt & Direkt \\
\hline Bakım Onarım & Endirekt & Direkt \\
\hline Gözetim & Endirekt & Direkt \\
\hline Üretim Destek Hizmetleri & Endirekt & Direkt \\
\hline Makine Amortismanı & Endirekt & Direkt \\
\hline
\end{tabular}

Kaynak: (KARCIOĞLU, 2000: 57)

Modern üretim sistemlerinde ve teknolojilerindeki gelişmelerin geleneksel maliyet muhasebesine diğer bir önemli etkisi dağıtım anahtarları üzerine olmuştur. Direkt işçiliğin eski önemini kaybetmesi, bu kalemin gider dağıtımında dağıtım anahtarı olarak kullanılmasını olumsuz yönde etkilemiştir (Karakaya, 2004: 568). Ayrıca, geleneksel maliyet muhasebesinde kullanılan dağıtım anahtarları hacim tabanlıdır. Modern üretim sistemlerinin gelişmesiyle birlikte, faaliyetlerin ön plana çıkması, hacim tabanlı dağıtım anahtarları yerini faaliyet tabanlı dağıtım anahtarlarına bırakmasına sebep olmuştur. 
- Ankara Üniversitesi SBF Dergisi • 62-4

\subsection{Tam Zamanında Üretim Yönteminin ve Toplam Kalite Yönetiminin Etkileri}

Tam zamanında üretim yöntemi ile toplam kalite yönetiminin geleneksel maliyet muhasebesine etkileri çok geniş kapsamlı olmuştur. Bu etkiler genel olarak dört başlık altında ifade edilebilir:

\subsubsection{Direkt Olarak İzlenebilen Maliyet Kalemlerinin Sayısında Artış}

Tam zamanında üretim yöntemi sahip olduğu özellikler nedeniyle, geleneksel maliyet muhasebesinde endirekt gider olarak kabul edilen maliyet kalemlerinin büyük bir kısmının direkt olarak izlenebilmesini sağlamaktadır (Karcığlu, 2000: 135). Örneğin; makinelerin ve cihazların amortismanı, bakım- onarım, enerji gibi kalemler, tam zamanında üretim yönteminde direkt olarak izlenebilmektedir.

\subsubsection{Maliyet Havuzlarının Sayısında Azalma}

TZÜY'nün temel amaçlarından birisi olan değer yaratmayan faaliyetlerin ortadan kaldırılması endirekt maliyetlerin sayısını önemli ölçüde azaltmaktadır. TZÜY'de stok düzeylerinin minimum düzeyde olması ve kaliteli üretim; kusurlu ürünlerin, hurdaların, 1skartaların sıfır düzeyine yakın olmasına ve işletmelerde yapılan stok işlemlerinin sayısının azalmasına neden olmuştur. Ayrıca bu gelişmeler, bu kalemler için ayrılan stok alanlarını gereksiz kılmıştır. Bunun en önemli etkilerinden birisi ilk madde ve malzemeler üzerine olmuştur. TZÜY'de satın alınan ilk madde ve malzemeler doğrudan üretime verildiği için, ilk madde ve malzemelere ilişkin satın alma ve üretime verme işlemleri ve bu işlemler için kullanılan maliyet havuzlarının sayısı azalmıştır (Pekdemir, 1998: 19).

\subsubsection{Dağıtım Anahtarları}

Geleneksel maliyet sistemlerinde kullanılan dağıtım anahtarlarından bir kısmı tam zamanında üretim yöntemi ile ortadan kalkmaktadır (Pekdemir, 1998: 19). Geleneksel sistemde yer alan, ancak, tam zamanında üretim yönteminde değer yaratmayan faaliyetler grubunda yer alan faaliyetlere ilişkin dağıtım anahtarları da geçerliliğini yitirmektedir. 


\subsection{4. İşletmenin Bütününe Yönelik Performans Değerlendirmesinin Öneminin Artması}

TZÜY, ișletmenin bütününü hedeflediğinden, ișletmenin her bir bölümünün performansının yerine, tüm işletme performansının karar alma sürecinde dikkate alınmasını gerektirmektedir (Hacırüstemoğlu/Şakrak, 2002: 73).

GÜS'de üzerinde önemle durulan standartlar ve fark analizleri, TZÜY'de önemini yitirmiştir. Geleneksel maliyet sistemlerinde geliştirilen standartlar ve fark analizleri işletmenin bir bütün olarak değerlendirilmesini de engellemektedir (Pekdemir, 1998: 20). Geleneksel maliyet muhasebesi sistemi standart maliyet sistemini kullanırken, modern maliyet muhasebesi kaizen maliyetlemeyi kullanmaktadır. Kaizen maliyetleme bir ürünün üretim aşamasında maliyet azaltımı için uygulanan bir yöntemdir. Kaizen maliyetleme sürekli gelişim felsefesini benimsemektedir. Üretim sürecinin etkinliğini arttırmak için gösterilen çabalar sürekli olmalıdır. Kaizen maliyetleme, mevcut ürünlerin üretim maliyetlerini, üretim sürecinin etkinliğini artırarak düşürür. Özellikle, çok kısa ömürlü ürünler üreten pek çok firmada, üretim süreci, ürünün ömründen uzundur. Dolayısıyla, üretim sürecine yoğunlaşılarak daha fazla maliyet tasarrufu elde etmek mümkündür (Kaplan/Cooper, 1998: 58).

TZÜY, geleneksel maliyet muhasebesinde endirekt gider olarak kabul edilen birçok maliyet kaleminin direkt gider olarak izlenebilmesini sağlamaktadır. Tam zamanında üretim yöntemi, üretim için gerekli ilk madde ve malzemelerin gerektiği anda siparişinin verilmesi anlayışıyla çalıştığından ilk madde ve malzemeler için geleneksel üretim sistemlerinde karmaşık olan satın alma, depolama ve kalite kontrol süreçlerini basitleştirmiş ve bu süreçlerde değer yaratmayan faaliyetlerin ortadan kaldırılmasını sağlamıştır. TZÜY'de, değer yaratmayan faaliyetlerin ortadan kaldırılması, bu faaliyetlerin yüklenmesinde kullanılan dağıtım anahtarlarını da etkilemiştir. Örneğin; depolama maliyetleri, geleneksel maliyet muhasebesinde endirekt gider olarak kabul edilmektedir. $\mathrm{Bu}$ maliyetlerin dağıtılmasında dağıtım anahtarı olarak genelde depolama alanı kullanılmaktadır. TZÜY'de depolama alanının olmaması, depolama alanının dağıtım anahtarı olarak kullanılmasını engellemektedir. Geleneksel satın alma düşüncesinde, büyük miktarlarda ve/veya tutarlarda satın alma, çeşitli iskontolardan yararlanmayı sağlamaktadır. TZÜY'de satın alma maliyetleri, uzun dönemli anlaşmalarla düşürülmeye çalışılmaktadır. Diğer bir deyişle, satın alma fiyatı yanında toplam maliyet de dikkate alınmaktadır (Pekdemir, 1998: 18-19).

TZÜY, maliyet muhasebesini geleneksel yapısının dışına çıkmaya zorlamaktadır. Bu nedenle, TZÜY'de maliyetlerin daha sağlıklı hesaplanmas1 önem kazanmaktadır. Maliyet bilgilerinin daha doğru bir şekilde 
saptanabilmesi, işletme yönetiminin karar alma sürecinde hatalı kararların alınmasını önleyecektir. TZÜY işletmenin bütününü dikkate alarak maliyet azaltımını benimsediğinden, maliyet muhasebesi sisteminin finansal olmayan ölçümleri de ifade edebilmesi gerekmektedir. Ayrıca, TZÜY işletmenin tüm faaliyetlerinin kolaylaştırılmasını öngördüğünden, maliyet muhasebesi sistemi de buna uygun olarak daha basit yapıda olmalıdır (Hacırüstemoğlu/Şakrak, 2002: 68).

TZÜY' deki muhasebe kayıt süreci ile geleneksel maliyet muhasebesindeki kayıt süreci karşılaştırmalı olarak şu şekilde ifade edilebilir (YÜKÇÜ, 1999: 807-808):

Geleneksel Muhasebe:

Kontrol $\rightarrow$ Stoklar $\rightarrow$ Üretim $\rightarrow$ Satışa Hazır Ürün

Tam Zamanında Üretim Yöntemi:

İlk Madde ve Malzeme ve Üretim Süreci $\rightarrow$ Satışa Hazır Ürün

Geleneksel maliyet muhasebesi sisteminde, satın alınan ilk madde ve malzeme kalite kontrol işleminden geçirildikten sonra stoklara alınmaktadır. Tam zamanında üretim yönteminde ise satın alınan ilk madde ve malzeme direkt üretim bölümüne aktarılmaktadır. $\mathrm{Bu}$ nedenle, tam zamanında üretim yönteminde ilk madde ve malzemenin stoklanması ile ilgili muhasebe kayıtları yer almamaktadır. İlk madde ve malzemenin stoklanmaması nedeniyle, ilk madde ve malzemenin üretim sürecinde detaylı kayıtlarla takip edilmesi söz konusu değildir. Satın alınan ilk madde malzeme geleneksel muhasebe sisteminde stoklar hesabına alınırken, tam zamanında üretim yönteminde yarı mamul üretim hesabına aktarılmaktadır. Geleneksel üretim sistemi itme prensibine göre çalışması nedeniyle, üretim süreci sonunda yarı ürünler ve ürünler stoku oluşmaktadır. Maliyetler de, öncelikle stok hesaplarına daha sonra satılan mamuller maliyeti hesabına kaydedilmektedir. Tam zamanında üretim yönteminin çekme prensibine göre çalışması nedeniyle, yarı ürünler ve ürünler stoku ortadan kalkmaktadır. Diğer bir ifadeyle, tam zamanında üretim yönteminde, yarı ürün ve ürün stokları bulunmamaktadır. Üretimi tamamlanan ürünler yarı mamul-üretim hesabından çıkartılmaktadır. Buna karş1lık, satılan mamuller maliyeti hesabının borcuna kayıt yapılmaktadır.

Geleneksel maliyet muhasebesi üzerinde etkili olan diğer bir önemli unsur toplam kalite yönetimidir. Kalitenin rekabetin temel faktörlerinden birisi olması ve kalite yönetiminin işletmenin bütününe yayılması zorunluluğu, geleneksel maliyet muhasebesinde önemli bir yer tutmayan kalite maliyetlerinin ön plana çıkmasına neden olmuştur. Kalite maliyetleri; önleme, değerlendirme, içsel başarısızlık, dışsal başarısızlık maliyetlerinin toplamından oluşmaktadır. Ancak, gerek tek düzen muhasebe sistemi, gerek dünyadaki muhasebe 
sistemlerinde kalite maliyetleri yer almamaktadır. Kalite maliyetlerinin sağlıklı bir şekilde hesaplanmasına duyulan ihtiyacın artması nedeniyle, kalite maliyetleri muhasebe sistemlerinde yer almalıdır. Rekabet gücünü arttırmak için işletme yönetimi, karar alma ve analiz sürecinde, kalite maliyetlerine özel önem vermek zorundadır. Kalite maliyetlerinin muhasebe sisteminde yer alması, muhasebe sisteminin daha ayrıntılı olmasına neden olabilir. Diğer yandan, kalite maliyetlerinin muhasebe dışında bırakılması ise bu maliyetlerin üretimle ilgili bölümlerden sağlanması söz konusu olabilir. Ancak, bu bölümlerden sağlanan kalite maliyetleri ile ilgili bilgilerin, işletme yönetiminin gereksinim duyduğu zaman ve gereksinim duyduğu şekilde üretilmiş olması gerekmektedir (Hacırüstemoğlu, 2000: 325).

\subsection{Genel Üretim Giderlerinin Hesaplanmasında Meydana Gelen Değişim}

Geleneksel maliyet sistemlerinde genel üretim giderlerinin ürünlere yüklenmesindeki temel prensip, belli bir dönemde, belli bir üretim sürecinde yapılan tüm üretim giderlerinin ürünlerin üretimi için yapıldığının varsayılmasıdır. $\mathrm{Bu}$ nedenle de, üretim giderleri ile ürünler arasında ilişki kurularak maliyet çalışması yapılmaktadır. Maliyet yönetiminin temelini oluşturan faaliyet tabanlı maliyetleme (activity based costing) yönteminde ise, belli bir üretim döneminde belli bir üretim sürecinde yapılan üretim giderleri, üretim sürecindeki faaliyetler için yapılmaktadır. Ürünler ise bu faaliyetlerden yararlanılarak üretilmektedir. Bu yaklaşımda, genel üretim giderleri ürünlere iki aşamada yüklenmektedir. Birinci aşama, genel üretim giderlerinin faaliyetlere yüklenmesi ve faaliyetlerin maliyetlerinin hesaplanmasıdır. İkinci aşama, faaliyetlerin maliyetlerinin ürünlerin faaliyetlerden yararlanma derecelerine göre dağıtılmasıdır (Büyükmirza, 2000: 264-265).

Faaliyet tabanlı yaklaşım sayesinde, işletme yönetimi, özellikle iki konuda daha sağlıklı bilgiler elde edebilecektir: Kaynak etkinliği ve faaliyet etkinliği. Kaynak etkinliği ile faaliyetlerin hangi kaynakları tükettiği belirlenecektir. Faaliyet etkinliğinin ölçülmesi, ürün üretim sürecinde değer yaratmayan faaliyetlerin saptanmasını ve ortadan kaldırılmasını sağlayacaktır. Değer yaratmayan faaliyetlerin saptanması, kaynakların (girdilerin) daha etkin kullanımını mümkün kılacaktır. Değer yaratmayan faaliyetler üzerindeki çalışmalar, tam zamanında üretim yönteminin etkinliğini ve kalite maliyetlerinin düzeyini de etkileyecektir (Karakaya, 2004: 570-571).

Modern üretim sistemlerinin sermaye yoğun teknolojilere sahip olmas1 nedeniyle teknoloji maliyetleri büyük bir sıçrama göstermiştir. Özellikle, 
- Ankara Üniversitesi SBF Dergisi • 62-4

teknoloji maliyetleri ile ilgili üç durum ortaya çıkmaktadır (Karakaya, 1999: 73-75):

-Teknolojik yatırımların muhasebeleştirilmesi,

-Teknolojik yatırımların hizmet sürelerinin belirlenmesi,

-Teknolojik yatırımların amortisman giderlerinin ürün maliyetlerine yüklenmesi.

Teknolojik yatırımlarla ilgili en önemli sorunlardan birisi, bu yatırımların amortismanıdır. Teknolojik yatırımların amortismanını belirlemedeki ilk adım, bu varlıkların hizmet sürelerinin belirlenmesidir. Teknolojik gelişmelerin baş döndürücü bir hızla arttığ günümüzde, teknolojik varlığın işletmeye yararlı olacağı süreyi belirlemek kritik derecede önemli olmaktadır. Çünkü bu varlıkların teknolojik ömürleri, ekonomik yararlarından daha kısa olmaktadır.

Teknolojik varlıkların amortismanı ile ilgili ikinci bir husus seçilen amortisman yöntemidir. Geleneksel muhasebe sistemi zaman esasına göre amortisman yöntemlerini (normal amortisman, azalan bakiyeler vb.) benimsemiştir. Modern üretim sistemlerinde, faaliyet tabanlı muhasebe kullanılması nedeniyle, seçilen amortisman yönteminin de faaliyet tabanlı olması ve ürünlerle direkt ilişkilendirilmesi gerekmektedir.

\section{SONUÇ}

Gerek üretim sistemleri ve teknolojilerindeki gelişmeler gerek küreselleşme, geleneksel maliyet muhasebesinin işletme yönetiminin karar alma sürecindeki etkinliğini azaltmaktadır. İşletmeler günümüzün rekabet koşullarında varlıklarını sürdürmek ve rekabet güçlerini artırmak için geleneksel maliyet muhasebesi düşüncesinden ayrılıp modern maliyet muhasebesi yöntemlerini kendilerine adapte etmelidirler. Çünkü günümüzün rekabet koşullarında geleneksel üretim sistemleri ve geleneksel maliyet muhasebesi yöntemleri ile işletmeler varlıklarını sürdüremeyecektir. Diğer yandan modern üretim sistemlerini uygulayan işletmeler de geleneksel maliyet muhasebesini kullandıkça istenen sonuçlar elde edilemeyecektir. Bu nedenle işletmelerin hem modern üretim sistemlerini hem de modern maliyet muhasebesi yöntemlerini kullanmaları gerekmektedir. Özellikle, işletmelerin küresel ölçekli rekabette, rekabet güçlerini arttırmak için yeni maliyet muhasebesi ve yönetim muhasebesi yöntemlerine ihtiyaç duyulmaktadır. Bu amaçla geliştirilen üç yöntem mevcuttur: Faaliyet tabanlı maliyetleme, hedef maliyetleme ve ürün yaşam seyri maliyetleme yöntemleridir. Her üç yaklaşım, birbirlerini tamamlayan yaklaşımlardır. Küresel ölçekli rekabette maliyetlerin düşürülmesi, üretim öncesi aşamalarda ortaya çıkan maliyetlerin yönetimi ile 
mümkün olmaktadır. Hedef maliyetleme de bu amaçla ortaya çıkmıştır. Diğer yandan küresel ölçekli rekabette sadece üretim öncesi ve üretim aşaması değil, üretim sonrası aşamalardaki maliyetlerin de dikkate alınarak analizlerin yapılması gerekmektedir. Ürün yaşam seyri maliyetleme yöntemi de, bir ürünün tasarım aşamasından, pazardan çekilinceye kadar olan tüm aşamalarda ortaya çıkan maliyetlerin yönetimi ile ilgilenmektedir.

\section{Kaynakça}

ATKINSON, Anthony A./ BANKER, Rajiv D./ KAPLAN, Robert S/ YOUNG, S.Mark (1997), Management Accounting (USA: Prentice Hall, 7th).

BÜYÜKMIRZA, Kamil (2000), Maliyet ve Yönetim Muhasebesi (Ankara: Barıș Kitap Basın Yayın Dağıtım, 8. Baskı).

COKINS, Gary (1996), Activitiy-Based Cost Management Making It Work (USA: McGraw-Hill Companies)..

ÇELIKÇAPA, Feray Omdan (1999), Üretim Planlaması (İstanbul: Alfa Basım Yayım Dağıtım).

ÇETINKAYA, Kerem (2000), Toplam Tasarım (Ankara: Gazi Kitabevi).

DEMiR, M.Hulusi / GÜMÜŞOĞLU Şevkinaz (2003), Üretim Yönetimi (İstanbul: Beta Basım Yayım Dağıtım, 6. Bası).

EDMANDS Thomas P./EDMANDS Cindy D./TSOY Boyi/SCHNEIDER Nancy W. (2003), Fundemental Managerial Accounting Concept, 2th, (New York, USA: International Edition, McGrawHill).

GÜNEŞ, Mustafa /FIRUZAN, Ali Rıza / FIRUZAN, Esin (1999), Tam Zamanında Üretim Ortamında Stok Kontrolü ve Toplam Kalite Yönetimi (İzmir: Fakülteler Kitabevi Barıș Yayınları).

HACIRÜSTEMOĞLU, Rüstem (2000), Maliyet Muhasebesi (İstanbul: Türkmen Kitabevi).

HACIRÜSTEMOĞLU, Rüstem / ŞAKRAK, Münir (2002), Maliyet Muhasebesinde Güncel Yaklaşımlar (İstanbul: Türkmen Kitabevi).

KAPLAN, Robert S. / COOPER Robin (1998), Cost Effect (USA: Harvard Business School Press).

KARAKAYA, Mevlüt (2004), Maliyet Muhasebesi (Ankara: Gazi Kitabevi).

KARAKAYA, Mevlüt (1999), “Yeni Üretim Ortamlarında Ürün Maliyet Unsurlarının Bileșimi ve Teknoloji Muhasebesi," Muhasebe Bilim Dünyası Dergisi, Cilt:1 Sayı:2, 1999.

KARCIOĞLU, Reșat (2000), Stratejik Maliyet Yönetimi (Erzurum: Aktif Yayın Dağıtım).

KOBU, Bülent (2003), Üretim Yönetimi (İstanbul: Avcılol BasımYayın, 11. Baskı).

LUCEY, T. (2000), Management Accounting (London UK.: Continuum)

PEKDEMIR, Recep (1998), Faaliyet Tabanlı Maliyetleme ve Genel Imalat Maliyetleri (İstanbul: TESMER Yayın No:17).

TOP, Aykut (2001), Üretim Sistemleri (İstanbul: Alfa Basım Yayım Dağıtım, 3. Baskı).

YÜKÇÜ, Süleyman (2000), “JIT Üretim Sisteminin Maliyet Muhasebesi Uygulamalarına Etkisi,” Muhasebe ve Denetime Bakış, Yıl:1 Sayı:1.

YÜKÇÜ, Süleyman (1999), Yönetim Açısından Maliyet Muhasebesi (İzmir: Cem Ofset). 